\title{
Thinking on the Cultivation of Applied Talents in Local Colleges and Universities
}

\author{
Huang Naizhu \\ Xiangnan University \\ Chenzhou Hunan Province 423000
}

\author{
Jiang $\mathrm{Li}^{*}$ \\ Xiangnan University \\ Chenzhou Hunan Province 423000
}

\begin{abstract}
The transitional development of local colleges and universities meets the needs of China's economic and social development and the adjustment of higher education structure. The transition from a local college to a university of applied sciences which aims to cultivating applied talents must achieve five core shifts: the principle of major setting shifts from the perspective of pedagogy to the perspective of sociology; the talent training programs must be changed from an academic perspective to an applied perspective; constructing versatile rather than one-dimensional teaching staff group; teaching model reform must shift from theoretical instruction to the cooperation of industry, learning and research; teaching management mode should change from rigid to flexible. As long as the five core shifts are implemented, the transitional development of local colleges and universities can be realized.
\end{abstract}

Keywords-local colleges and universities; transitional development; core shift

Based on the development trend of higher education, the needs of economic and social development, and the training of applied talents in colleges and universities, the transitional development of local colleges and universities carries out allround reforms in aspects such as school-running system, specialty construction, personnel training model, teaching staff construction, and management service model. We should make progresses on the original academic personnel training mechanism through reforms, and take into consideration the local economic development and the foundation for the development of local colleges and draw on the experience of universities of applied science in abroad, to establish the universities that meet the needs of China's local economic and social development to serve local economic and social development. At present, "the ratio of technical talents and academic talents in developed countries in Europe is generally $8: 2$, which is in line with the structure of talent demand for socio-economic development, and the University of Applied Sciences is an important organization for training applied talents." [1] In transitional development, local colleges and universities shouldn't chasing blindly for the high school positioning, instead, they should grow to be the universities of applied science with their own characteristics according to their history and strength of running a school. This is not only the inherent necessity of structural adjustment of higher education, but also a wise choice for the sustainable development of local universities

\section{PRINCIPLE OF MAJOR SETTING: SHIFTING FROM PEDAGOGY TO SOCIOLOGY}

The traditional majors of local colleges follow the path of pedagogy that majors are "special studies" based on subject knowledge classification system. And talent cultivation is centering on academic talent education to set training programs, courses, and carry out education and teaching work. The education model which focuses on systematic and theoretical knowledge, has been proved to be inefficient to meet the needs of transformation and upgrading of local industrial structure, or to cultivate the applied talents needed for local economic and social development. Local colleges and universities shall shift their focus from the perspective of pedagogy to the perspective of sociology set majors, that is, they decipher the major as the "profession" of the social professional classification system, so that the professional education is the vocational professional education which is to cultivate applied talents who learn to meet practical needs. According to the principle of major setting under sociology, the local undergraduate colleges are required to adjust and optimize the major structure according to the idea of "serving the local economy by bridging majors with industry chain and promoting the development of local industries by docking characteristic disciplines with regional advantages". In addition, they need to behave actively to withdraw a batch of majors that can hardly match with local economic and social development, so as to concentrate on the development of a number of applied technical disciplines and majors better fit with local economic structure. They should strive to build a number of prosperous professionals with certain advantages and characteristics of the schools, which can generate significant social and economic benefits. By promoting integration of disciplines, they can achieve bridging between professional groups and regional industry chains, and enable the professional groups to contribute more to local economic and social development and improve professional competitiveness of disciplines.

\section{REQUIREMENTS OF TALENT TRAINING PROGRAM:}

TURNING FROM ACADEMIC PURPOSE TO APPLIED PURPOSE

To take the cultivation of applied talents as the orientation for running a school, local colleges and universities are required to shift their focus from academic training to applied training to set talent training programs. As we all know, the traditional talent training programs in local colleges are based on the discipline system and center on the academic talent training to set curriculum, select teaching materials, and 
introduce teachers. And the selection of teaching methods which focuses on academic training rather than applied training makes the talents too weak in practice and innovates to meet the needs of local economic restructuring and development, resulting in structural unemployment among local university graduates. The applied talent training programs require local colleges and universities to take applied talents cultivation as the starting point to formulate professional talent training programs. Based on that, we must boldly learn from the successful experience of vocational education in local universities in Europe and the United States, and research and adopt advices from professionals in industries and enterprises. Professional courses and practical courses are closely set around the core professional abilities required by the industries and enterprises. Focusing on the organic integration of theoretical teaching and practical teaching, we need to increase investment in professional practice teaching hardware and strengthen effort in the teaching management reform, and cultivate talents that not only entertain solid theoretical and professional knowledge, but also have the ability to translate their knowledge into actual production, as well as problem analyzing and solving in production. Generally speaking, the talents can get started easily and quickly with development potential. They can grow coordinately in theory, knowledge, methods, and capabilities, acquire "extensive, specific and crossover" knowledge and form self-learning habits. Furthermore, they not only have the basic skills necessary for certain professional positions, but also have knowledge, technological innovation, technological secondary development capabilities, as well as the high quality for a variety of positions.

\section{STANDARD OF TEACHING GROUP: TURNING FROM ONE- DIMENSIONAL STAFF TO COMPOUND STAFF}

Colleges and universities are the ideal places for cultivating talents. Only truly competent people can undertake the task of cultivating talents [2]. The cultivation of applied talents in local colleges and universities requires a "composite" teaching group with sufficient high quality teachers and reasonable teaching structure. The teachers should have both career and academic experience, which means that they possess not only solid theoretical knowledge, high teaching level and scientific research capability, but also professional-related work experience and rich practical work experience. In local undergraduate colleges, the introduction and cultivation of academic teaching staff overweigh those of applied personnel, which led to the over-emphasis on theoretical knowledge in training at the expense of practical abilities or the separate of theory and practice. Under the circumstances, it is difficult to really cultivate applied talents who have strong ability to discover and solve practical problems. The transformation of the teaching staff of the local college from an academic to a compound type refers to regard the academic and practical teaching staff as equally important, and focus on the introduction and cultivation of teachers with a high academic standard and a certain experience in industry and enterprises. The "dual-qualified" teachers as an important resource in colleges and universities directly affect the quality of the training of applied talents. Practice has proved that compared with the traditional classroom teaching mode, the school- enterprise cooperation teaching models such as "embedded, integrated cooperative, segmented, order-type and postpractice" have enormous advantages, for they aim at strengthening students' social practice capabilities. The effective use of these teaching models requires a batch of "dual-qualified" teachers. Adhering to the principle of "respecting talents, people-orientation, complementary of advantages, mutual benefit, legal management, and joint development”, local colleges and universities should build a teaching group for application-oriented personnel training. First, we need to speed up the introduction of application-oriented majors as well as leading professionals and teaching backbones of high-level disciplines, giving full play to their role in guiding, stimulating and radiating the transformation and development of colleges and universities. Second, we need to actively introduce or hire high-level professional and part-time teachers with practical experience from industries (enterprises) following the principle of "do not ask for everything, but use it". In this way, we aim to adjust and optimize the structure of teaching staffs in universities. Third, we need to positively designate young and middle-aged core teachers to participate in social practice in industries (enterprises) based on the principle of "school-enterprise cooperation and mutual benefit". We aim to improve the teachers' practical and innovative ability and to effectively promote the in-depth integration of teachers' teaching theory and practice through training, investigating and participating in project researches. Fourth, we need to increase capital investments so as to actively build school-enterprise cooperation bases, participate in the $R \& D$ and construction of local science and technology industries, ensure the completion of the practice targets of young and middle-aged teachers, and realize the transformation of scientific research achievements.

\section{REFORM IDEA OF TEACHING MODEL: ENTERPRISE- UNIVERSITY-RESEARCH COOPERATION RATHER THAN THEORETICAL INSTRUCTION}

The cultivation of applied talents in local colleges and universities must reform the traditional theoretical instruction which aims to cultivate academic talents, emphasizes the theoretical and systematic nature of subject knowledge, underlines the dominant position of teachers in the teaching process, while neglects students' learning subjectivity and practicality. On the contrary, local colleges and universities must adhere to "industry-education integration", the production, learning and research coordinated teaching model that advocates multiple teaching methods such as projectorientation, task-driving, situation-immersing, case teaching, simulation teaching, and inquiry teaching. It is beneficial to cultivate the applied talents required for the adjustment of national economic structure to meet the needs of production, construction, management and service. The effective promotion of the cooperative teaching model of industry, universities, and research requires universities to actively dedicated themselves into the structural adjustment of regional economic and social development by policy guiding, take the initiative to establish development alliances with local governments and enterprises, and to create a training mechanism integrating teaching, research and service which is participated by varied parties and runs in various models. First, we should build the platform for innovative talents training. 
We should make a breakthrough in the single closed-end talent cultivation concept in universities. We endeavor to vigorously strengthen the close cooperation between schools and localities, universities, enterprises, councils, schools and so on according to the basic ideas of "majors dock industries, practices in training bases, scientific researches combine with production and education as well as projects advance teaching". Relying on universities and colleges and taking the teaching departments as the main body, we jointly cultivate modern applied talents with innovative spirit, practical ability and international quality. Second, we ought to expand teaching contents. We work hard to make a breakthrough in the simple theoretical knowledge conveyance. According to the principle of "combination of theory and practice", we energetically strengthen the study and researches of practical knowledge that closely related to the first line of production, construction, management and service, and strive to improve the basic skills of college students' qualification for professional positions as well as the secondary development and innovation capabilities of knowledge and technology. Third, we should establish a cooperation base for personnel training. Through the building of the coalition council system, universities along with localities and industries(enterprises) cooperate and build internship(training) and employment bases, comprehensive laboratories as well as the R\&D centers, and carry out cooperation in project development, two-level colleges building and titled classes hosting following the principle of voluntariness, equality and mutual benefit. In this way, universities can realize connection and sharing of talents, resources, projects and information along with localities and industries (enterprises), and to form a cooperation network with comprehensive, multi-level and close-knit joint applied talents training.

\section{REFORM REQUIREMENTS OF TEACHING MANAGEMENT: FLEXIBLE RATHER THAN RIGID}

The cultivation of applied talents requires a set of flexible teaching management operating mechanisms. Therefore, local colleges and universities must strive to explore and establish a new model of teaching management that is conducive to stimulating people, fostering people, and development. The traditional teaching management model is based on the controllability of the planned economy. It cannot really mobilize the enthusiasm and initiative of teachers and students in teaching and learning, because they are not free enough under the control. The flexible teaching management model advocates the values of freedom, choice and responsibility, and targets at fostering the consciousness of "learning and thinking freely" of college students. Jaspers has said that the mission of university education is to enlighten people's free nature through culture. It can be said that the competitive advantage of a university lies in encouraging teachers and students to freely pursue in many aspects. Any teaching plans and procedures are merely suggestions for helping students to focus in classes, and should not be used to limit students' freedom.

\section{A. Set up flexible school system and promote complete credit system}

The flexible teaching management model will give up the credit-based system and implement a complete credit system that originated from Harvard University in the 19th century. It is a kind of teaching management system that takes total credits as the graduation standard. It requires that the credits for each course be determined according to the training objectives and the amount of time for each course in the teaching plan and in the same way to set compulsory and optional courses, the proportion of various courses, and the minimum credits for students to graduate. At present, the credit system management implemented by local colleges and universities is a teaching management model based on control thinking. It is not a truly flexible schooling system. And it is difficult for students to complete credits ahead of schedule. Even if credits are achieved in advance, it is difficult to graduate earlier. The significance and effectiveness of the system are greatly reduced. Without a true elimination mechanism, the university has become almost a "safe deposit box", which means that as long as you are admitted into the university, you can get credits and diplomas without hard working. As a result, it is common that college students lack motivation in learning.

The flexible system requires a fundamental change in the concept of education management. "Education should have been the freedom of thought, judgment, feelings and imagination that they need to fully exert their talents and to control their own destiny as much as possible”. [3] Western countries focus on individual growth, follow the laws of nature, and allow students to grow naturally by interests, aspirations, and choices without external intervention. In contrast, the starting point of the talent cultivation concept in China is shaping, in which the one being educated is took as the raw material that is put in the standard mold and on the assembly line, giving birth to standard "products" with no personality, no creativity. That is the "characteristics" of Chinese school education. Establishing a flexible learning system and a credit system management will inevitably require universities to carry out in-depth management reforms and education and teaching reforms, and to allow students to choose subjects, courses, teachers, and time, by which to prompt schools to attach importance to the quality of personnel training. In the promotion of credit system management, colleges and universities strive to achieve the following tasks. First, provide a wealth of courses for students to choose independently. We know that in the foreign universities which implement credit system, required courses only accounted for about $40 \%$, whereas the proportion of optional courses is as high as $60 \%$. Second, the credit system management services for students should include employment services, student status management, boarding services, etc. Third, we must change the administratively-led distribution of educational resources, and set up colleague evaluation system among teachers in particular.

\section{B. Building and completing the flexible and open teaching management system that is conducive to students' individual orientation}

The highest level of education is to allow students to grow freely. Education is the best platform for building the 
foundation of a beautiful life through the shaping of personality, the passing of wisdom, pure, kindness, beauty, freedom, fairness, hope and love. Through the reform of teaching management, local colleges and universities can promote the teaching management system that is conducive to the individual orientation of students, such as training based on individuals, cultivation according to levels, staged cultivation, selective system and major-minor system, so as to provide institutional guarantee for the training of diversified personnel. At the same time, in addition to focusing on practical ability and innovation ability training, local colleges and universities should also provide courses in humanities and social sciences such as philosophy, ethics, history, sociology, and pedagogy to improve students' humanistic quality. In today's world, with the advancement of science and technology, the material progress is continuously improving, but social morality is declining day by day, and the survival crisis of human beings has become increasingly serious. "Science is a powerful tool. Whether it is to bring happiness to others or to bring about disaster, depends entirely on how people use it, not on itself. For example, knife is useful in human life, but it can also be used to kill others". [4] To this end, undergraduate students must acquire the two major humanistic qualities of the university through learning and thinking. The one is big state. It means that we should bear others in our hearts and entertain noble moralities, convictions and lofty ideals for life. Colleges need to set humanities read and cultivation as compulsory courses. By the profound cultural heritage and the integrity and elegance that modern intellectuals should have for their lives, university students can be taught to learn extensively and think deeply, be discerning and persistent, be virtuous and inclusive, learn to think about the meaning of life and pursue the ideal of life. Students should be inspired to dedicate themselves to learning without fickleness, be indifferent to fame and fortune, and aim high. The other is the big vision that can be translated into professional vision, broad social vision, and open international perspective."[5]

\section{CONCLUSION}

The transitional development of local colleges and universities is a systematic project which requires people to carry out comprehensive reforms in aspects such as the school system, professional construction, personnel training model, teaching staff construction, and management service model. The reputation of the school and the quality of applied talents will become better if we respond to social needs to set up majors, strengthen the construction of "dual-qualified" teacher group, formulate and implement applied talents training programs, and carry out reforms in teaching models and management models in accordance with the standards of applied talents.

\section{ACKNOWLEDGMENT}

The 2016 Hunan Province Ordinary Colleges and Universities Teaching Reform Research Project "Online Course Resources Construction and Teaching Application of Local Universities Under the Modern Information Technology” Xiangjiaotong [2016] No. 400.

\section{REFERENCES}

[1] Association of Universities(Colleges) of Applied Science Research Center of Transitional Development of Local Colleges and Universities. Report on the Transitional Development Practice and Policy of Local Universities.2013,13.

[2] Ma Yanqi. On University Teachers' Teaching Responsibility[J]. Journal of Higher Education,2008(5),24.

[3] UNESCO Education Development Committee,Learn The Treasure Within[R], Translated by Chinese Office of UNESCO,Beijing:Education Science Publishing House, 1996,78.

[4] Albert.Einstein.The Collected Works of Einstein Volume Three[G].Beijing:The Commercial Press, 1979,56.

[5] Hu Xiangfeng. What Should University Be?[N]. Guangming Daily. 2013.12.23.16 